Int. J. Morphol.,

33(2):719-724, 2015.

\title{
Variation in the Repair of a Rib Graft used for Mandibular Reconstruction after 20 years
}

\author{
Variación en la Reparación de un Injerto Costal Utilizado \\ para Reconstrucción Mandibular después de 20 años
}

\author{
Leandro Pozzer*; Sergio Olate ${ }^{* * * * * *}$; Márcio de Moraes*; Luciana Asprino* \& José Ricardo de Albergaría Barbosa*
}

POZZER, L.; OLATE, S.; DE MORAES, M.; ASPRINO, L. \& BARBOSA, J. R. A. Variation in the repair of a rib graft used for mandibular reconstruction after 20 years. Int. J. Morphol., 33(2):719-724, 2015.

SUMMARY: Mandibular reconstruction has been used in the last 100 years as a safe, effective and stable technique. Various types of grafts have been used, including the autogenous rib graft; the normal repair of this type of graft has been defined in some studies although some observations have been made indicating low predictability of the growth of this bone. The aim of this study was to report the case of a patient with a rib graft for mandibular reconstruction where after 20 years cartilaginous tissue was observed exclusively in the absence of bone tissue. A 61-year-old female patient presented in the Oral and Maxillofacial Surgery Service for dental implants. The patient had a history of 4 previous mandibular reconstructions; imaging showed no alterations to the normal evolution of a graft. However, the intraoral access contained softer tissue than the normal bone, and thus the implant installation was abandoned. Histopathological analysis revealed the formation of collagenous tissue and cartilage, chondrocytes island conditions characteristic of cartilaginous tissue in the absence of mineralization and cancellous bone. This led to the conclusion that repair conditions can vary based on specific and general factors as yet under discussion.

KEY WORDS: Bone graft; Rib graft; Bone repair.

\section{INTRODUCTION}

Mandibular reconstruction surgery has advanced substantially in recent years; nevertheless, a reconstruction that enables functional and esthetic recovery and that includes mandibular height and width as well as muscular insertion and integral dental recovery has not been achieved to date (Goh et al., 2008). Thus, mandibular reconstruction should allow function of the temporomandibular joint (TMJ) and the insertion of implants to manage patients' functional rehabilitation (Goh et al.).

Free bone grafts have been used since the beginning of the last century, when surgeons like Dr. Sykoff developed techniques for autogenous bone transplantation in the mandible. Since then, mandibular reconstruction has been indicated for the management of trauma sequelae, traumarelated substance loss and replacement of areas injured by extensive infections or for the management of benign or malignant tumors, obtaining stable results in most cases (Obwegeser, 1966).
The variety of bone grafts applied in mandibular reconstruction includes free bone grafts, cancellous particulate bone grafts, reconstruction with plates and alloplastic systems and microvascularized bone grafts, and finally, a series of related techniques can be applied including the use of titanium mesh, the use of biomaterials, and others.

Biologically, the success of these transplants lies in the revascularization of the bone graft with the decrease in micromovement that allows a stable bone repair and bone integration into the remaining segment of the mandible (Khadka \& Hu, 2011); thus, the bone formation at the reconstructed site responds to the normal physiological cycles of bone repair, where the resorption process and bone apposition present the standard times of any bone graft. Nevertheless, under some circumstances this physiological sequence can be altered, thereby limiting or delaying the normal physiological processes (Han et al., 2015).

* Division of Oral and Maxillofacial Surgery, State University of Campinas, Campinas, Brazil.

** Division of Oral and Maxillofacial Surgery, Universidad de La Frontera, Temuco, Chile.

**** Centre for Biomedical Research, Universidad Autónoma de Chile, Temuco, Chile. 
The aim of this report is to present the clinical case of a rib graft installed in the body of the mandible and stabilized as cartilaginous tissue.

\section{CASE REPORT}

A 61-year-old female patient presented in the Oral and Maxillofacial Surgery Service of the State University of Campinas, Brazil for surgical installation of dental implants and subsequent mandibular rehabilitation. The patient had used a removable partial prosthesis for nearly 40 years. In the initial examination, she reported the use of orally administered $50 \mathrm{mg}$ alendronate sodium once a week for 10 years for osteoporosis.

The patient presented for a right unilateral mandibular reconstruction undertaken in four previous stages. 41 years before, the diagnosis of a benign odontogenic tumor led to a right hemimandibulectomy with deferred reconstruction (1 year) based on a free iliac crest graft. The procedure failed and a year later the same reconstructive procedure was performed with a new iliac crest graft. The condition remained stable until 1985, when a new reconstructive surgery of the mandible was performed in the same sector, using a rib graft to provide adequate mandibular contour and function, fixed mainly with osteosynthesis wire.

Three years after this, a fourth rib graft was performed (obtained from the contralateral sector) to provide function and rehabilitate the patient (Fig. 1). 22 years later the patient came to our Service to have dental implants installed in the right mandibular sector, which prompted CT imaging (Fig. 2 ), where limited volume and morphology were observed, but the installation of implants was approved. Facially, there were no alterations and the intraoral inspection showed possible edentulous areas to manage with osseointegrated implants (Fig. 3a and 3b).

The intraoral surgical procedure began with a mandibular incision and bone exposure (Fig. 4) that permitted direct observation of the mandible; the access revealed the presence of tissue with little resistance to compression by surgical instruments, apparently with low mineralization, clinically closer to the properties of cartilage than bone. The implant installation was abandoned and an incisional biopsy was taken from the mandibular area.

The tissue was processed for histological study with routine techniques and hematoxylin and eosin staining. The images (Fig. 5a and 5b) revealed a differentiated connective tissue, chondrocyte islands and cartilaginous tissue with no presence of cell structures of the bone metabolism or histological characterization of the bone tissue. This information demonstrates that the tissue formation present in the area of mandibular reconstruction is non-mineralized tissue, making it incompatible with osseointegration processes; furthermore, this finding reveals the cartilaginous tissue formation from a rib graft, which casts doubts on the normal repair cycle observed in these tissues.

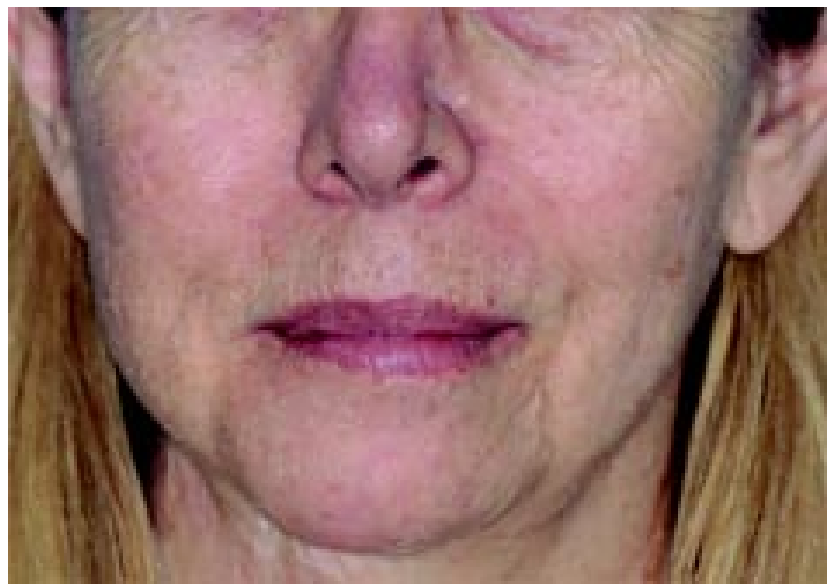

Fig. 1. Patient's face showing facial symmetry with no significant defects.

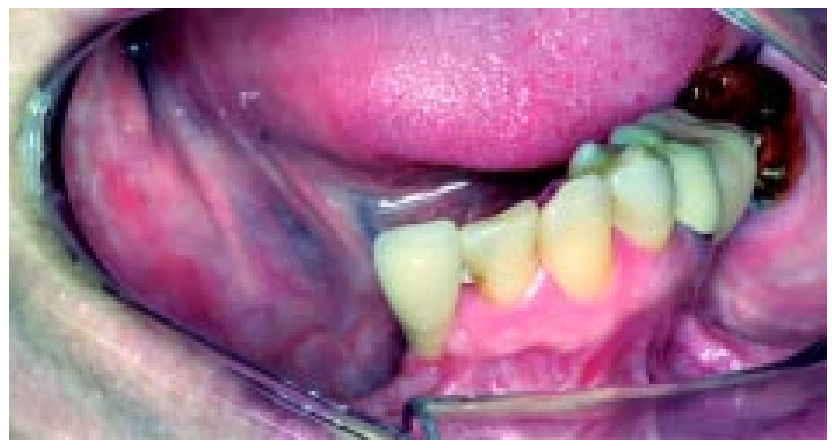

Fig. 2. Intraoral image that reveals bone decrease, limitation in volume of soft tissues and dental alterations of neighboring structures.

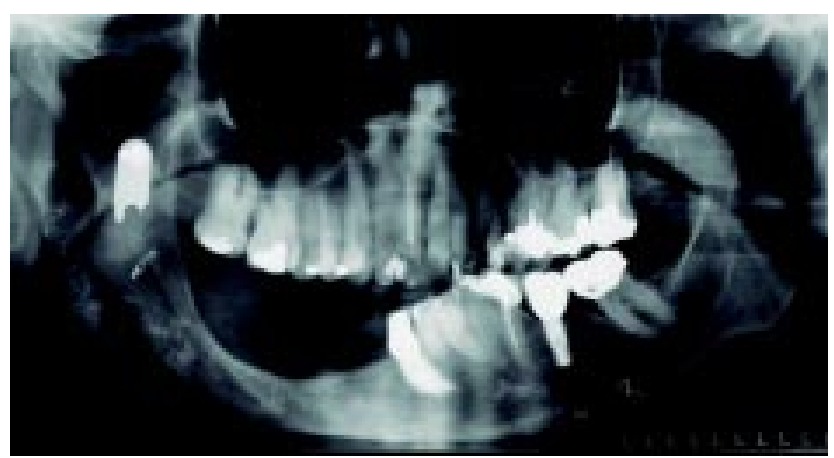

Fig. 3. Panoramic image displaying the right mandibular sector with mandibular reconstruction based on rib graft. Fixation with wire and remaining osteosynthesis plate are observed. 


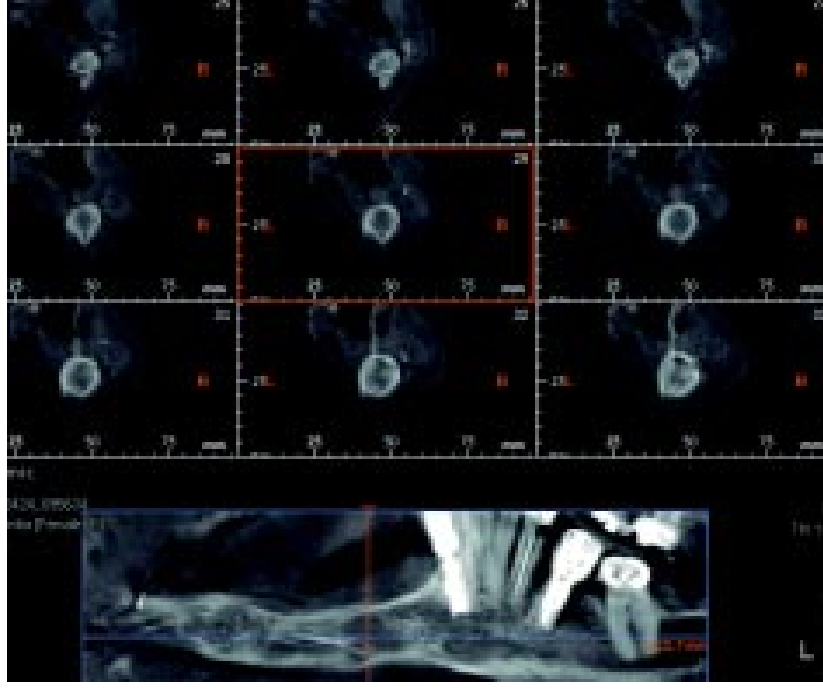

Fig. 4. 3D reconstruction using CBCT where area of probable cortical bone and medullar bone is observed.

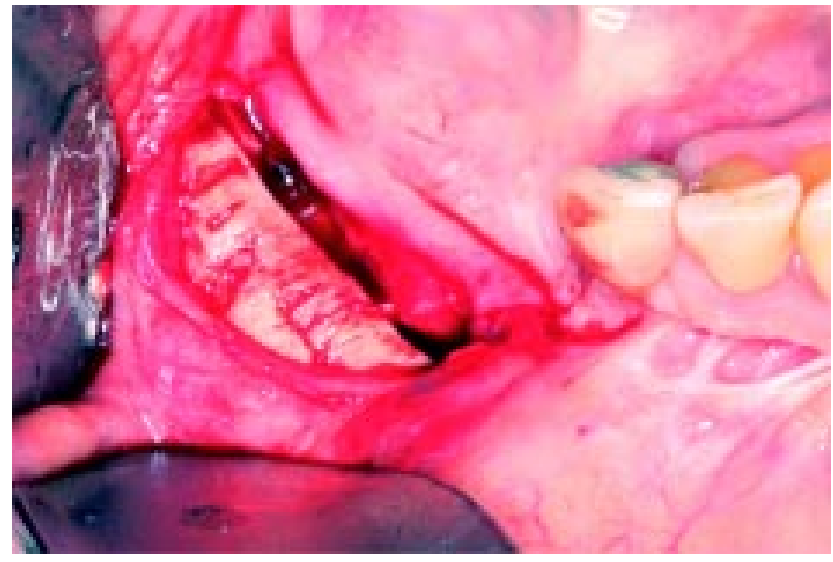

Fig. 5. Intraoral surgical access of posterior sector of mandible showing softened tissue, with no clinical characteristics of bone tissue.

\section{DISCUSSION}

Free bone grafts have been used under various conditions. Until the end of the 1970s the bone graft was stabilized and fixed with wires, combined with long periods of intermaxillary fixation. Today, the free bone graft is frequently transplanted from the anterior iliac crest in block form and stabilized at the reconstruction site with plates and titanium screws (Bak et al., 2010; Olate et al., 2013).

The success of this technique depends largely on the stability and immobility of the graft more than the inherent structural characteristics of the graft (Netto et al., 2013); revascularization of the graft ensures the natural bone remodeling, optimizing its recovery. Cases where the

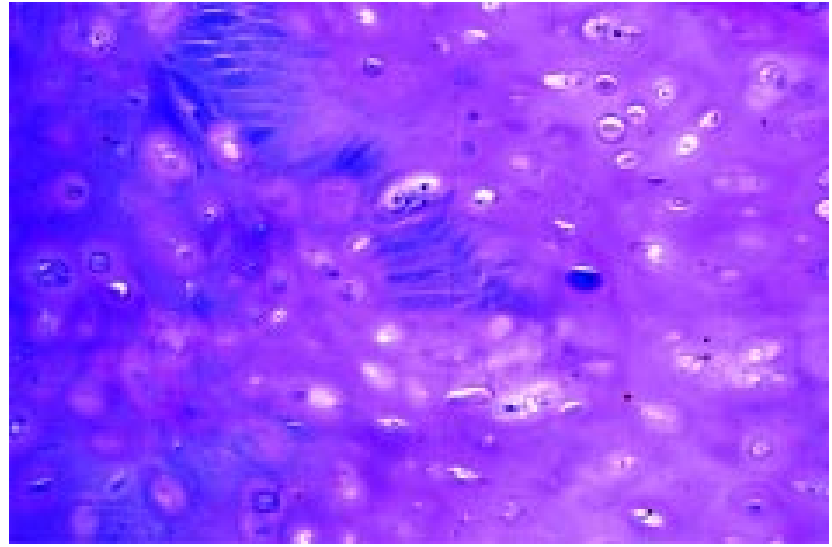

Fig. 6. Image where chondrocytes are observed in some sectors of the tissue biopsy and non-mineralized tissue (HE 100x).

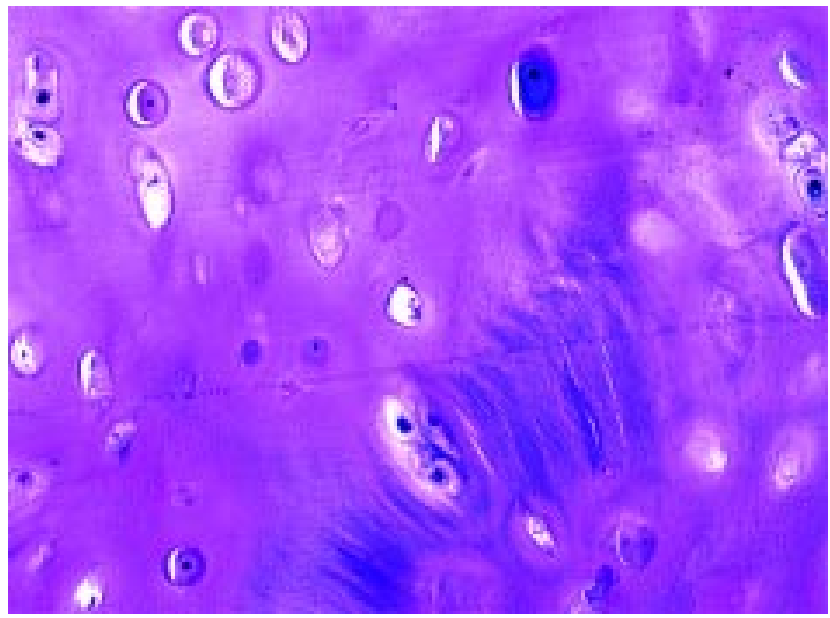

Fig. 7. Histological image (HE 25x) revealing the cellularity characteristic of cartilaginous tissue, with low population of blood vessels and absence of mineralized tissue.

transplanted block has not been adequately revascularized and integrated into the receptor site can lead to non-union, as observed by Kruger et al. (1984), who indicated the presence of this phenomenon in 15\% and 30\% of different study groups.

It is now recognized that free bone grafts are useful in the management of mandibular defects close to $5 \mathrm{~cm}$, providing good stability and coverage with soft tissues, although there are no studies that compare groups of vascularized bone grafts with non-vascularized free grafts (Goh et al.). In fact, there are no objective parameters that determine $5 \mathrm{~cm}$ as the maximum used in bone reconstruction with free grafts, even considering studies by Progrel et al. (1997) which indicate that under $9 \mathrm{~cm}$ non-vascularized free bone grafts would be efficient. Schlieve et al. (2015) established that iliac crest bone grafts for immediate reconstruction of mandibular resections can be used safely, 
reducing the times needed to execute the implant installation and rehabilitation.

The costochondral bone graft has been widely used in TMJ reconstruction in subjects with ankylosis of the TMJ; in this technique it is estimated that 2 to $3 \mathrm{~mm}$ of cartilage and the sixth or seventh rib could be useful in avoiding exaggerated growth of the cartilage area (El-Sayed, 2008); thus, its growth potential has been confirmed by other studies, giving it the value of acting in its cartilage form in replacement of the TMJ although its low predictability of its (more or less required) growth has also been observed (Baek \& Song, 2006).

The potential of the rib graft in terms of bone growth (in the case of subjects with TMJ replacement) has had varied results, being deficient in some cases that required a new bone graft procedure (Guyuron \& Lasa, 1992). This variation is also accompanied by the fact that in some cases new ankylosis appeared in the cartilage sector of the TMJ, presenting in 5 and 39\% (Elgazzar et al.; Rahaman \& Mao, 2005). The conditions described reflect the response variability that the rib graft confers on normal function. This variability can also respond to the condition observed in this case where the variation is reported from bone tissue (rib) to cartilaginous tissue.

The rib bone presents a poor cortical and spongy structure compared to the mandibular bone and has greater flexibility than compact bones, which is useful for ribcage function (Khadka \& Hu). These anatomical variations may partly explain the disparities in the observed growth; nevertheless, Abdel-Haleem et al. (2011) reported a followup of almost 40 patients with reconstruction in different areas of the facial skeleton using a rib as the element of reconstruction with no reports of failures or complications related to the reconstruction site. Banerjee \& Westmore (1995) showed a series of 11 patients receiving a rib graft with no alterations in bone repair, although in neither of these investigations were histological studies conducted in the control phases.

Considering that in this case the bone graft had been performed more than 20 years earlier, the causes of the formation of cartilaginous tissues can vary: 1) being the fourth mandibular reconstruction surgery may influence the low vascularization of the area combined with an impoverishment in periosteum function (Ostrup \& Tam, 1982). It is recognized that VGEF expression and angiogenesis are necessary for bone regeneration (Klüppel et al., 2013), which acts within the physiological process of the bone metabolism. The limited vascular function in this sector may be an influential factor. In addition, cartilage requires less irrigation for its function than bone does, which would also respond to the condition observed (Chen et al., 2015). However, the development of a hypertrophic cartilage in its final stage determines bone growth through endochondral methods, of low mechanical resistance, and is a physiopathological process that could influence this patient's condition (Chen et al.). In fact, during skeletogenesis in the embryological stage, the initial formation of basic cartilage is avascular at first; when the chondrocytes finalize their hypertrophy process, they are invaded by blood vessels (Maes, 2013).

Similarly, the independent repair of cartilage with defects greater than $3 \mathrm{~mm}$ is not viable, unlike the conditions observed at bone level with critical defects (Mollon et al., 2013); it is likely in this case that physiological mechanisms established for the development and stability of the cartilage are generated with the inverse formation from bone to cartilage. Vascularization of this system plays an important role, considering that the comparison of vascularized and non-vascularized grafts in an animal model revealed that integration to the adjacent bone was faster in the vascularized grafts, although all of them achieved adequate bone formation in the 20 and 30week follow-ups (Evans et al., 1991).

On the other hand, 2) the stability of the bone graft may also have influenced the bone repair. Stability, achieved today with plates and osteosynthesis screws, is a fundamental factor in tissue repair, allowing the normal transit of blood vessels and nutrients to the graft site (Hagiwara et al., 2015). Pereira-Filho et al. (2013) determined that with the use of reconstruction plates, the application of one or two screws in each end of the plate could cause certain levels of instability, recommending the use of three screws for fixation. The fixations placed when this patient was subjected to reconstructive processes were done with osteosynthesis wires, giving limited stability in the sector.

Finally, 3) a hypothesis that can be proposed from this condition lies in the growth potential that the rib can exhibit. When the rib is combined with chondral elements, its growth potential has been reported in other studies (Elgazzar et al., 2010), demonstrating that there is a certain autonomous response based on the function and formation of anatomical structures. This hypothesis can be confirmed with experimental animal models, because this response may be fundamental in future studies conducted to better understand the current phenomenon in this patient.

This patient's condition was stable for years. Despite being a tissue with cartilaginous component in the mandible, masticatory function was maintained with a removable 
prosthesis and motor and sensory function were maintained with adequate mobility of the mandible and insertion of muscle tissues, and no complications were observed in these characteristics. It can be concluded that the characteristics of bone repair from a rib graft can vary from normal bone formation to cartilaginous tissue formation.

POZZER, L.; OLATE, S.; DE MORAES, M.; ASPRINO, L. \& BARBOSA, J. R. A. Variación en la reparación de un injerto costal utilizado para reconstrucción mandibular después de 20 años. Int. J. Morphol., 33(2):719-724, 2015.

RESUMEN: La reconstrucción mandibular ha sido utilizada en los últimos 100 años como una técnica segura, eficaz y estable. Diversos tipos de injertos se han utilizado siendo el auto trasplante de hueso costal uno de ellos; la normal reparación de este tipo de injertos ha sido definida en algunas investigaciones aunque se han realizado otras observaciones indicando baja predictibilidad del crecimiento de este hueso; el objetivo de esta investigación es reportar un caso de una paciente portadora de injerto costal para reconstrucción de mandíbula donde después de 20 años se observó exclusivamente tejido cartilaginoso en ausencia de tejido óseo. Una paciente del sexo femenino, 61 años se presentó al Servicio de Cirugía Oral y Maxilofacial para ser tratada con implantes dentales; la paciente presentaba historia de 4 reconstrucciones mandibulares previas; los estudios de imagen se presentaban sin alteraciones a la condición normal de la evolución. Sin embargo, al acceso intraoral se observó un tejido más blando que el hueso normal, abortándose la instalación del implante. El análisis histopatológico reveló la formación de tejido colágeno y cartílago, condrocitos en lagunas y condiciones características de tejido cartilaginoso en ausencia de mineralización y trabeculado óseo.Se concluye que las condiciones de reparación pueden variar en base a factores específicos y generales aun en discusión.

PALABRAS CLAVE: Injerto óseo; Injerto costal; Reparación ósea.

\section{REFERENCES}

Abdel-Haleem, A.; Nouby, R. \& Taghian, M. The use of the rib grafts in head and neck reconstruction. Egyptian J. Ear Nose Throat Allied Sci., 12(2):89-98, 2011.

Bak, M.; Jacobson, A.; Buchbinder, D. \& Urken, M. Contemporary reconstruction of the mandible. Oral Oncol., 46(2):71-6, 2010.

Baek, R. M. \& Song, Y. T. Overgrowth of a costochondral graft in reconstruction of the temporomandibular joint. Scand. J. Plast. Reconstr. Surg. Hand. Surg., 40(3):179-85, 2006.

Banerjee, A. R. \& Westmore, G. A. Free rib graft reconstruction of the mandible: a forgotten option?. Ann. R. Coll. Surg. Engl.; 77(4):278-82, 1995.

Chen, S.; Fu, P.; Cong, R.; Wu, H. \& Pei, M. Strategies to minimize hypertrophy in cartilage engineering and regeneration. Genes Dis., 2(1):76-95, 2015.

Elgazzar, R. F.; Abdelhady, A. I.; Saad, K. A.; Elshaal, M. A.; Hussain, M. M.; Abdelal, S. E. \& Sadakah, A. A. Treatment modalities of TMJ ankylosis: experience on Delta Nile, Egypt. Int. J. Oral Maxillofac. Surg., 39:333-42, 2010.

Evans, H. B.; Brown, S. \& Hurst, L. N. The effects of early postoperative radiation on vascularized bone grafts. Ann. Plast. Surg., 26(6):505-10, 1991.

El-Sayed, K. M. Temporomandibular joint reconstruction with costochondral graft using modified approach. Int. J. Oral Maxillofac. Surg., 37(10):897-902, 2008.
Goh, B. T.; Lee, S.; Tideman, H. \& Stoelinga, P. J. Mandibular reconstruction in adults: a review. Int. J. Oral Maxillofac. Surg., 37(7):597-605, 2008.

Guyuron, B. \& Lasa, Jr. C. I. Unpredictable growth pattern of costochondral graft. Plast. Reconstr. Surg., 90(5):880-6, 1992.

Hagiwara, Y.; Dyment, N. A.; Jiang, X.; Huang, J.; Ackert-Bicknell, C.; Adams, D. J. \& Rowe, D. W. Fixation stability dictates the differentiation pathway of pariosteal progenitor cells in fracture repair. J. Orthop. Res., 33(7):948-56, 2015.

Han, D.; Han, N.; Zhang, P. \& Jiang, B. Local transplantation of osteogenic pre-differentiated autologous adipose-derived mesenchymal stem cells may accelerate non-union fracture healing with limited pro-metastatic potency. Int. J. Clin. Exp. Med., 8(1):1406-10, 2015.

Khadka, A. \& Hu, J. Autogenous grafts for condylar reconstruction in treatment of TMJ ankylosis: current concepts and considerations for the future. Int. J. Oral Maxillofac. Surg., 41(1):94-102, 2011.

Klüppel, L. E.; Antonini, F.; Olate, S.; Nascimento, F. F.; AlbergariaBarbosa, J. R. \& Mazzonetto, R. Bone repair is influenced by different particle sizes of anorganic bovine bone matrix: a histologic and radiographic study in vivo. J. Craniofac. Surg., 24(4):1074-7, 2013

Kruger, E. \& Krumholz, K. Results of bone grafting after rigid fixation. J. Oral Maxillofac. Surg., 42(8):491-6, 1984. 
POZZER, L.; OLATE, S.; DE MORAES, M.; ASPRINO, L. \& BARBOSA, J. R. A. Variation in the repair of a rib graft used for mandibular reconstruction after 20 years. Int. J. Morphol., 33(2):719-724, 2015.

Maes, C. Role and regulation of vascularization processes in endochondral bones. Calcif. Tissue. Int., 92(4):307-23, 2013.

Mollon, B.; Kandel, R.; Cahhal, J. \& Theodoropoulos, J. The clinical status of cartilage tissue regeneration in humans. Osteoarthritis Cartilage, 21(12):1824-33, 2013.

Netto, H. D.; Olate, S.; Klüppel, L. E.; do Carmo, A. M.; Vásquez, B. \& Albergaria-Barbosa, J. R. Histometric analysis of cancellous and cortical interface in autogenous bone grafting. Int. J. Clin. Exp. Pathol., 6(8):1532-7, 2013.

Obwegeser, H. L. Simultaneous resection and reconstruction of parts of the mandible via the intraoral route in patients with and without gross infections. Oral Surg. Oral Med. Oral Pathol., 21(6):693-705, 1966.

Olate, S.; Netto, H. D.; Klüppel, L. E.; Vásquez, B.; Chaves, M. G. A. M. \& del Sol, M. Comparison of Bone Graft Healing Between Autogenous Bone, Blood Clot and Anorganic Bovine Bone Matrix: Radiographic and Histological Analyses. Int. J. Morphol., 31(4):1257-62, 2013.

Ostrup, L. T. \& Tam, C. S. Bone formation in a free, living bone graft transferred by microvascular anastomoses. Scand. J. Plas. Reconstr. Surg., 40(2):122-6, 1982.

Pereira-Filho, A.; da Silva, B. N.; Nunes Reis, J. M.; Spin-Neto, R.; Real Gabrielli, M. F. \& Monnazzi, M. S. Effect of the number of screws on the stability of locking mandibular reconstruction plates. Int. J. Oral Maxillofac. Surg., 42(6):732$5,2013$.

Pogrel, M. A.; Podlesh, S.; Anthony, J. \& Alexander, J. A comparison of vascularized and nonvascularized bone grafts for reconstruction of mandibular continuity defects. J. Oral Maxillofac. Surg., 55(11):1200-6, 1997.

Rahaman, M. N. \& Mao, J. J. Stem cell-based composite tissue constructs for regenerative medicine. Biotechnol. Bioeng., 91:261-84, 2005.

Schlieve, T.; Hull, W.; Miloro, M. \& Kolokythas, A. Is immediate reconstruction of the mandible with nonvascularized bone graft following resection of benign pathology a viable treatment option? J. Oral Maxillofac. Surg., 73(3):541-9, 2015.
Correspondence to:

Prof. Dr. Sergio Olate

División de Cirugía Oral y Maxilofacial

Universidad de La Frontera

Claro Solar 115, Oficina 414-A

Temuco

CHILE

Email: sergio.olate@ufrontera.cl

Recibido : 10-02-2015

Aceptado: 22-03-2015 